\title{
Corporate Social Responsibility_-From the Perspective of Polish Enterprises
}

\author{
Katarzyna Olejniczak \\ Czestochowa University of Technology, Czestochowa, Poland
}

\begin{abstract}
Corporate social responsibility (CSR) is becoming more and more frequently emphasized part of management in the structure of Polish enterprises. These results from the fact that growing awareness of consumers, destructive impact of industry on the natural environment, economic scandals, unethical behavior among entrepreneurs, bring about redefining the principles of a business activity on the market by entrepreneurs. As a result of the above, such values as honesty, trust, or responsibility take on greater importance. Additionally, more and more often, Polish entrepreneurs pay attention to the influence of the company on the environment, the way the stakeholders are treated, while striving to maximize profit. The present paper looks into the subject of social responsibility from the point of view of Polish enterprises. To verify this objective, there was the analysis of the due literature performed, and also carried out the survey among 174 entrepreneurs running their business activity in the area of Southern Poland. The research tool used in the research was the questionnaire (PAPI and CAWI). In the conducted research, there were factors analyzed referring to knowledge of social responsibility among the people holding both managerial and lower-level positions, in particular opinion, is it important for enterprises to be driven by ethical standards? How to implement CSR in their structures? How to understood concept of CSR? What are the reasons for the implementation of CSR in the strategy of the company? The considerations (both the theoretical and practical ones) confirmed that the Polish enterprises feel the increased need to implement the activities in the field of social responsibility, which, in the present conditions, constitutes an important part of running a business activity.
\end{abstract}

Keywords: corporate social responsibility (CSR), development stages of CSR in Poland, good practices, aspects of CSR

\section{Introduction}

In the era of global economy, running a business based on the assumptions of the concept of social responsibility significantly influences its relationships in the environment, since CSR is an example of the concept, its inception has been evolving and maturing, and in spite of this, its popularization still encounters resistance. This results from the fact that, in the conditions of the Polish market, social responsibility appeared relatively recently, and its knowledge is either very poor or very superficial.

Katarzyna Olejniczak, Ph.D., Department of the Business Management, Faculty of Management, Czestochowa University of Technology.

Correspondence concerning this article should be addressed to Katarzyna Olejniczak, Al. Armii Krajowej 19b, 42-200 Częstochowa, Poland. E-mail: k.olejniczak@zim.pcz.pl. 
The aim of the paper is to present and also to show the results of the research concerning the concept of social responsibility from the perspective of Polish enterprises. The conducted research was to assess the knowledge concerning social responsibility in the enterprises running their business activity in the area of Southern Poland. While referring to the main problem of the paper, there are defined the following conditions concerning the identification of CSR in Polish enterprises, which constitute the basis for the interpretation of the obtained research results:

- Part of modern management is to balance economic objectives with ethical actions;

- Polish enterprises feel the increased need for the implementation of activities in the field of social responsibility;

- CSR constitutes, in the present conditions, an essential part of running a business activity.

On the basis of the above, there was submitted the thesis that social responsibility is of the key importance for Polish enterprises.

\section{Social Responsibility-The Concept Arousing Interest}

The appearance of social responsibility both in theory and practice of management aroused many debates and controversies from the very beginning. This result from the fact is that the concept changed the previous model of business thinking, in which the basic goal of the enterprise activity was profit (Friedman, 1980), while enforcing the reorganization of its perception by including social and ecological issues into everyday business practice (Ingley, 2008, p. 18).

As Carroll and Buchholtz (1999) rightly notice, "within the last three decades, a large number of people dealing with business enthusiastically have become the followers of the CSR concept, but relatively little consensus was achieved on the concept of CSR itself' (p. 27). These results from the fact that there are no strict boundaries, since, while taking into consideration specific business conditions, each branch or even an organization may create its own, individual understanding of this concept. Moreover, each of the authors describing social responsibility actually emphasizes other elements of this idea. Initially, this concept was recognized as the entrepreneur's duty to apply such a policy, take such decisions or follow such directions, which were the desired goal and value for the society (Olejniczak, 2012, p. 16). This rather general statement describing the essence of CSR escalated over time into more precise and accurate terms.

Social responsibility is "taking business decisions connected with ethical values, compliance with legal requirements and respect for people, the community and the environment” (Murrey, 2003, p. 11).

While moving the discussion into the Polish reality, the definition by Adamczyk (2009) undoubtedly deserves a special attention, stating that:

Social responsibility may be interpreted as a commitment to transparent and ethical business according to the principles of sustainable development and in the pursuit of social welfare, taking into account the expectations of stakeholders, but in accordance with the law and standards of behavior. (Adamczyk, 2009, p. 10)

Drucker extremely aptly described the essence of social responsibility. According to him, "social responsibility of managers requires such proceedings that let all, which actually is the public interest, become the enterprise own interest" (Drucker, 1994, p. 418). Therefore, enterprises ought to make an attempt at internationalization of the expectations they face. These results from the fact are that the activities of enterprises are no longer merely aiming at profit maximization, but learning and including the changing social 
and ecological expectations into management strategy. According to the statement by Griffin and Ebert (2006), social responsibility obliges enterprises to "keep the balance in the activities for the benefit of groups in their environment, including the clients, other organizations, employees, investors and local communities" (Griffin \& Ebert, 2006, p. 68).

At this point, it is necessary to pinpoint that the activities in the field of CSR are simultaneous activities which, on the one hand, exceed the framework of legal regulations, whereas, on the other hand, they are voluntary activities, referring to considering social and ecological aspects in everyday activity of the enterprise and contacts with a wide range of stakeholders.

\section{Social Responsibility in Poland}

While discussing CSR in Poland, it is necessary to remember that it is the country of a relatively "young" market economy, having been formed only since 1989. Previous experiences, connected with a long period of the communist regime, significantly determined the nature of Polish entrepreneurship, and the way the society perceives the role of the private sector (Ćwik, 2011, p. 21). Therefore, initially, social responsibility was treated as the barrier impeding further development, and market success, connected with the above. Figure 1 shows the development of CSR in Poland.

As it is possible to notice (Figure 1), in the initial period of development, Polish enterprises were not interested in the activities in the field of CSR. Therefore, this stage is defined as "the stage of silence". In the second stage, in 2000-2002, social responsibility brought about aversion, and sometimes even objection and aggression of the majority of the business leaders or economic publicists, convinced of the fact that free market is a cure for all problems. The initial interest in, even fashion for, the public declarations of the acknowledgement of the role of the CSR principles occurred only in 2002-2004. It was from this period that there appeared the development of specific, though partial projects, including the selected, significant areas of the functioning of companies in the field of CSR (stage 4). The last stage of the development of social responsibility, lasting since 2006, is the stage initially chaotic, since there was an attempt to link CSR to other strategies (marketing, personnel, communication etc.) (CSR in Poland: Baseline study, 2007, p. 22).

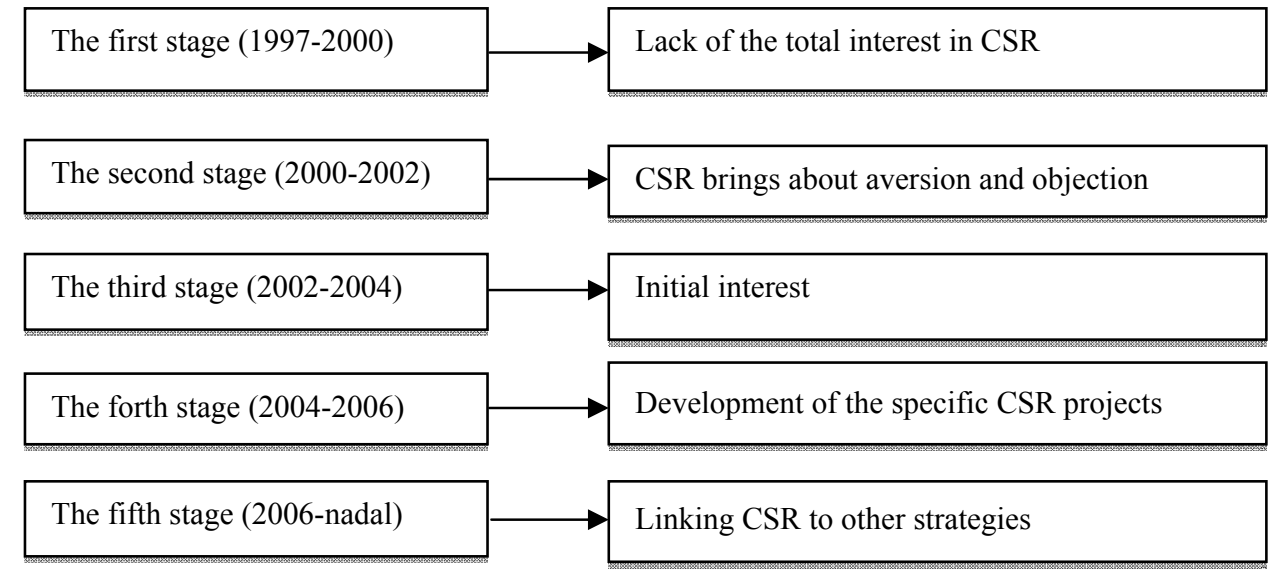

Figure 1. Stages of development of CSR in Poland. Source: The author's own research based on Kroik and Bachorski-Rudnicki, 2010, p. 18.

Nowadays, Polish enterprises are catching up the most popular western trends in the field of CSR, while implementing a range of so-called good practices. 
Good practices are in the area of interests of Responsible Business Forum, which, for the last 11 years, has been publishing the Report "Responsible business in Poland. Good practices", in a complex way, moving the activity of Polish enterprises in the field of CSR activities in the following categories: business, market, environment, management, and workplace. Table 1 presents the detailed list of socially responsible projects for 2005-2010.

Table 1

Socially Responsible Projects in Poland for 2005-2010

\begin{tabular}{lllllll}
\hline Categories of socially responsible projects & 2005 & 2006 & 2007 & 2008 & 2009 & 2010 \\
\hline Business and workplace & 21 & 14 & 9 & 16 & 15 & 12 \\
Business and society & 27 & 38 & 24 & 35 & 37 & 58 \\
Business and market & 12 & 16 & 14 & 12 & 20 & 20 \\
Business and environment & - & - & 8 & 25 & 20 & 17 \\
Management and reporting & - & - & - & - & 3 & 10 \\
\hline
\end{tabular}

Note. Source: Olejniczak, 2013, p. 44.

Since 2011, in accordance with the international norm ISO 26000, concerning social responsibility, this report has contained an additional category, i.e., organizational governance (see Table 2).

Table 2

Good Practices in Poland in 2011-2012

\begin{tabular}{lcc}
\hline Areas of good practices & 2011 & 2012 \\
\hline Organizational governance & 18 & 24 \\
Human rights & 5 & 3 \\
Labor aspects & 66 & 60 \\
Natural environment & 37 & 44 \\
Fair market practices & 8 & 16 \\
Consumer issues & 4 & 17 \\
Involvement and development of the local community & 71 & 98 \\
\hline
\end{tabular}

Note. Source: Olejniczak, 2013, p. 45.

While analyzing the data in Table 2, it is necessary to conclude that in 2011, in the report, there were 209 good practices of management described, which were sent by 106 enterprises, whereas in 2012, 262 practices, also described by 106 enterprises. Both in 2011 and 2012, the dominating area of pro-social activity was actions in the field of social commitment and development of local community, labor aspects, and also the activities aiming at the improvement of the natural environment, for example, good practices are implemented by the enterprises such as: PKN ORLEN, Zywiec Group, Kompania Piwowarska, TP Group, ENEA Capital Group, Credit Agricole, Lotos Group, Fortum Power and Heat Poland, Tchibo Poland, Henkel Poland, Carlsberg Poland, Danone Poland and many others.

\section{The Method of the Empirical Research and the Characteristics of the Respondents Research Design}

The presented results were formulated on the basis of the results of the survey conducted in the first quarter of 2014 among enterprises operating in the area of Southern Poland. The research tool used in the research was the questionnaire (PAPI and CAWI) addressed to 174 enterprises. It is necessary to pinpoint that 
the conducted research was fully anonymous and the participation in it was voluntary.

In the research most enterprises from the SME sector took part (see Figure 2), in diversified activity-73\% of the respondents, out of which, $31.6 \%$ are micro-enterprises, employing up to nine people, $27.6 \%$ are small enterprises, employing $10-49$ people, $13.8 \%$ are medium enterprises, employing $50-249$ people, $23 \%$ of the enterprises under research are large enterprises, employing more than 251 employees.

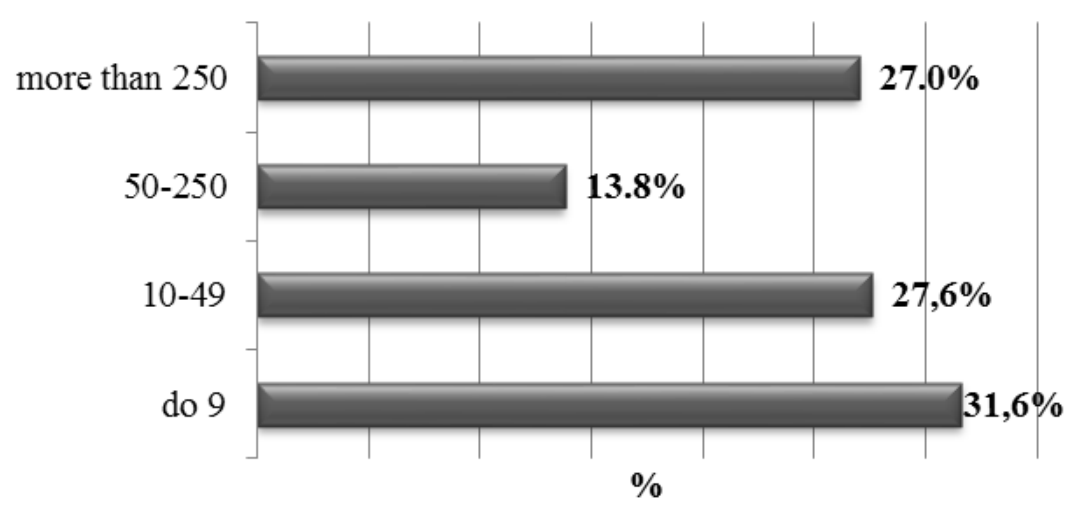

Figure 2. The structure of the enterprises under research by the level of employment.

The characteristics of the respondents were also regarded from the point of view of the market they operate on (see Figure 3). On the basis of the obtained data, it is possible to state that the enterprises under research are characterized by a rather wide range of the attended markets: There are $48.2 \%$ of the enterprises operating in the area of the whole country, $33.3 \%$ on the local market, $15.8 \%$ on the world market, and $2.6 \%$ on the regional market.

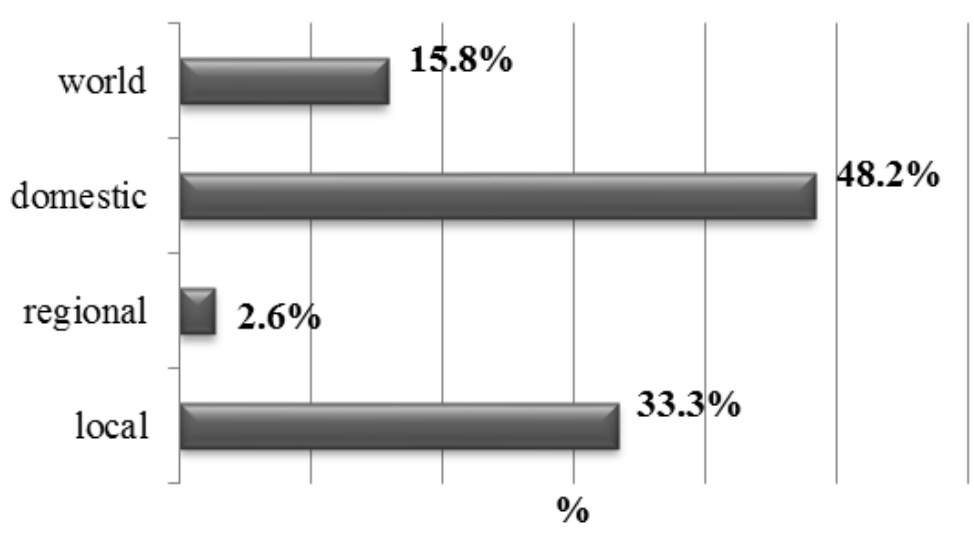

Figure 3. The structure of the enterprises under research by the attended market.

Another criterion, according to which there were enterprises characterized under research, was their market position (see Figure 4). The majority of the enterprises recognized their market position as the stable one (36.8\%), 33.3\% assessed it as the developing one, $22.4 \%$ - as the leader's position, $7.5 \%$ of those questioned acknowledged that their market position has been declining year by year.

The object of the research was both the management staff (46\%) and people in lower-level positions $(54 \%)$. 


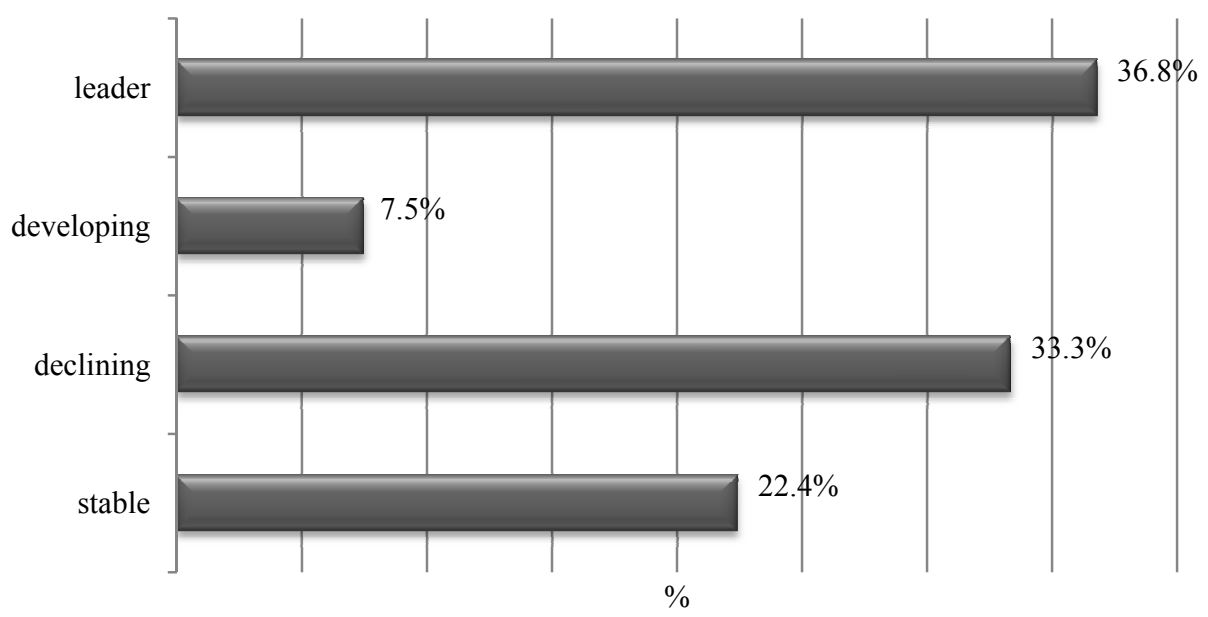

Figure 4. The structure of the enterprises under research by the market position.

\section{The Results of the Survey}

In the conducted research, there were factors analyzed referring to knowledge of social responsibility among the people holding both managerial and lower-level positions.

At first, the respondents were asked to express their opinion on the activity of enterprises in Poland (see Figure 5), and consequently, whether they should take into consideration social good in their business activity (see Figure 6).

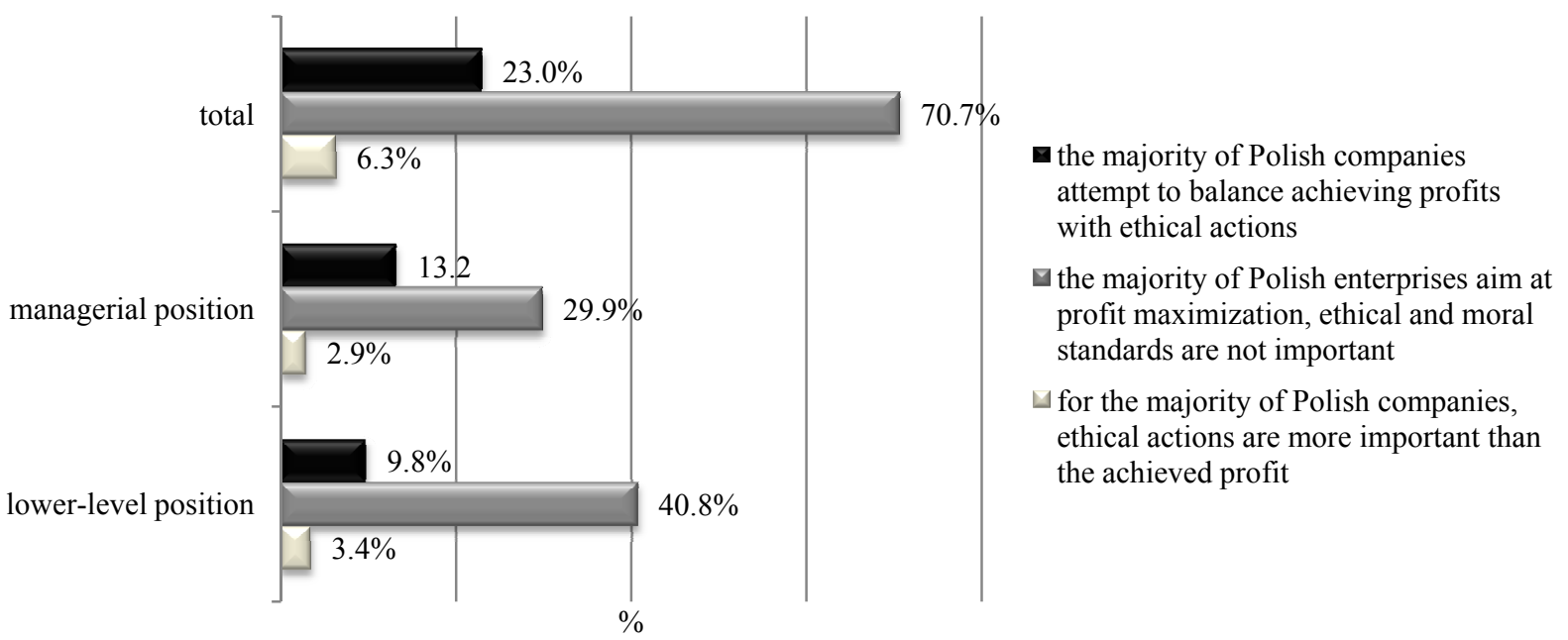

Figure 5. The opinion on the activity of enterprises in Poland.

The analysis of the research material indicated that according to $70.7 \%$ of those questioned (both holding the managerial and lower-level positions), the activity of the majority of Polish companies is consistent with the statement by Friedman (1980), according to whom the basic goal of the enterprise activity is profit. In practice, this means taking decisions which bring about generating profit and increase in the enterprise value, and therefore, the activities connected with the realization of the basic business goals, excluding ethical and moral issues, $32 \%$ of the respondents express a different opinion, claiming that Polish enterprises more and more 
frequently balance making profit with ethical activities. In turn, $6.3 \%$ perceive the necessity of the implementation of ethical activities above the ones connected with gaining economic benefits.

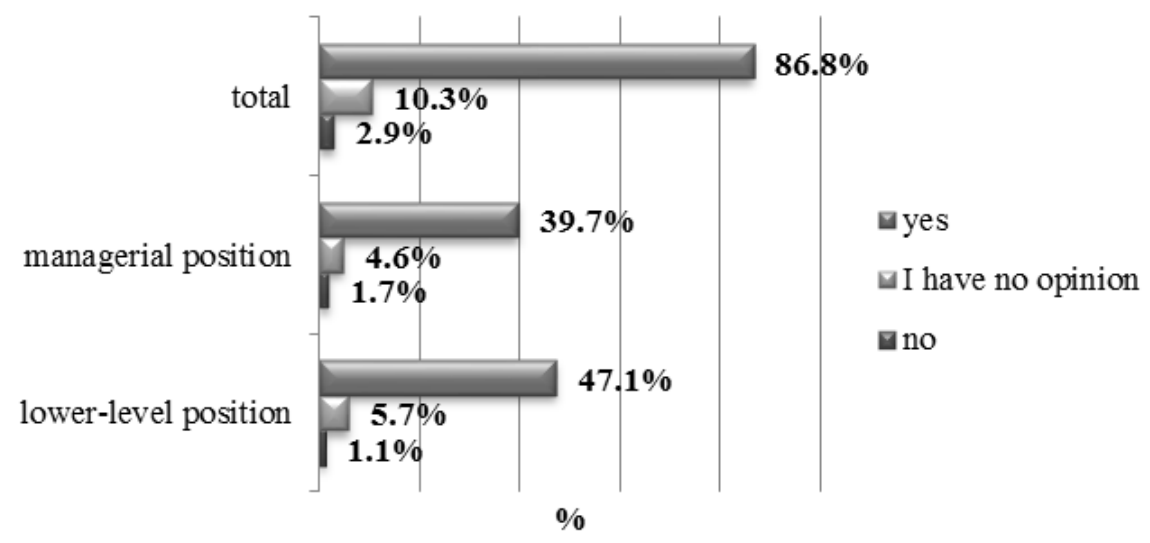

Figure 6. The necessity of taking into consideration social actions in the business activity in the opinion of Polish enterprises.

In spite of the fact that the majority of the respondents expressed the opinion that in the activity of Polish enterprises ethical actions are not important, $86.8 \%$ acknowledged that they should include social good in their activity. Therefore, it is possible to assume that the previous model of business thinking will change, and ethical actions, and also social responsibility will constitute an essential part of management, which is confirmed by the obtained research results (see Table 3).

Table 3

The Significance of Ethical Actions and the Ones Socially Responsible in the Opinion of Polish Entrepreneurs

\begin{tabular}{|c|c|c|c|c|}
\hline \multirow{3}{*}{ Responses } & \multicolumn{4}{|c|}{ In your opinion, is it important for enterprises } \\
\hline & \multicolumn{2}{|c|}{ To be driven by ethical standards? } & \multicolumn{2}{|c|}{ To implement CSR in their structures? } \\
\hline & $N=174$ & $\%$ & $N=174$ & $\%$ \\
\hline Yes & 162 & $93.1 \%$ & 146 & $83.9 \%$ \\
\hline I have no opinion & 8 & $4.6 \%$ & 25 & $14.4 \%$ \\
\hline No & 4 & $2.3 \%$ & 3 & $1.7 \%$ \\
\hline Total & 174 & $100 \%$ & 174 & $100 \%$ \\
\hline
\end{tabular}

On the basis of the data presented in Table 3, it is possible to state that business requires ethical standards in spite of aiming at profit maximization. The majority of the respondents (162) expressed such an opinion, acknowledging that being driven by ethical standards is an important element of the modern company. According to those questioned, it is important that enterprises, including the Polish ones, introduced the activities in the area of CSR in their structures, 146 respondents expressed such an opinion.

At this point, it is necessary to underline that an important problem of the implementation of CSR in Poland is lack of knowledge in this field. Still, many entrepreneurs treat CSR as sharing profit, not the activities connected with building reputation and gaining trust of the people working in the company, as well as the ones from the environment of the enterprise. Therefore, from the point of view of the aim of the conducted research, it was important to receive the response to the question: Have you ever come across the term of CSR? (see Figure 7). 


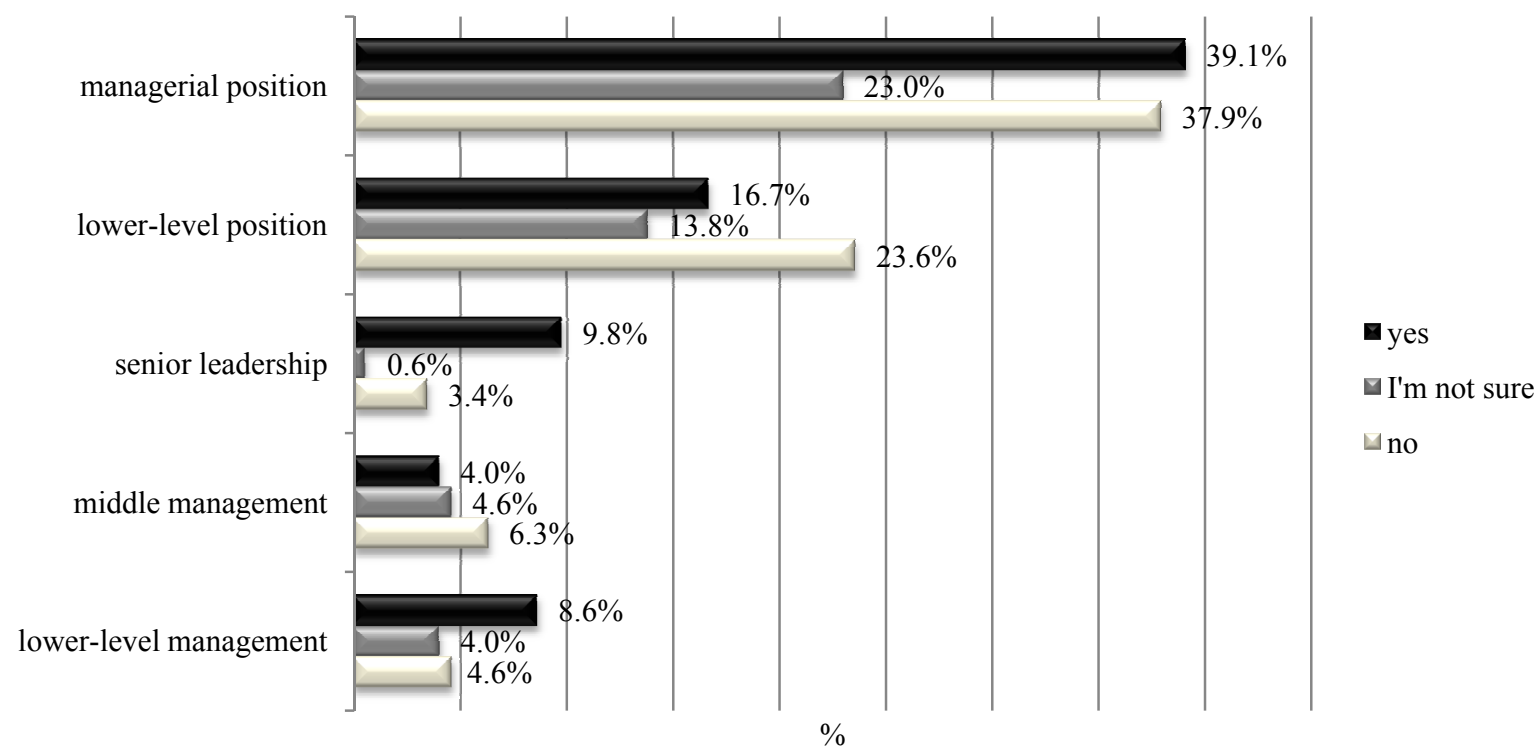

Figure 7. The knowledge of the term of social responsibility in the opinion of Polish enterprises.

While analyzing the obtained results (see Figure 7), it is possible to state that only $39.1 \%$ of those questioned came across the term of CSR, 23\% were not completely sure whether this term was known to them, and $37.9 \%$ of the respondents did not come across this concept. While making further analysis, it is possible to notice that the knowledge of the concept of CSR is visible in the group of people holding managerial posts-22.4\%, out of whom $9.8 \%$ are the senior leadership and $8.6 \%$ - lower level management, $4 \%$-middle management. At this point, it is necessary to pinpoint that, year by year, the awareness of Polish entrepreneurs is growing with reference to the issues connected with the concept of social responsibility. The research conducted by the author in 2010 among 82 Polish entrepreneurs indicated that as much as $61 \%$ did not know the concept of CSR, $18 \%$ were not sure, and only $21 \%$ came across the idea of CSR (Olejniczak, 2012, p. 32).

The obtained research results also allowed to specify how the respondents understand the activity which is socially responsible. According to them, by the concept of CSR the followings are understood:

- building positive image of the company both outside and inside the enterprise (19\%);

- compliance with legal regulations and ethical standards (19\%);

- care of employees (their development, workplace, and opportunity to participate in managerial processes in the company) (17\%);

- involvement in the activities exceeding the basic business activities of the company (15\%);

- relationships with stakeholders and the entire environment (12\%).

Nine percent of the respondents admitted that social responsibility constitutes a new concept of management of the contemporary enterprise, bringing about the achievement of so important competitive advantage. Also, $9 \%$ of those questioned defined CSR as the strategy of the company bringing about a range of advantages, including the financial ones.

From the point of view of the aim of the research, it was important to specify the fields of the activity of the enterprise, which is socially responsible. On the basis of the obtained research results, it is possible to conclude that in the opinion of Polish companies, the enterprise which is socially responsible, should, above all: 
- comply with health and safety regulations and rights of workers;

- minimize negative impact on the environment;

- get involved in providing help to local communities;

- bring about the solution of social problems.

The detailed distribution of the responses is presented in Table 4.

Table 4

The Reasons for the Implementation of CSR in the Opinion of Polish Enterprises

\begin{tabular}{lcc}
\hline In your opinion, what are the reasons for the implementation of CSR in the strategy of the company? & $N=345 \%$ \\
\hline Better image of the company in a crisis situation & 104 & $30 \%$ \\
Higher profits & 30 & $9 \%$ \\
Care of the condition of the natural environment & 42 & $12 \%$ \\
They are enforced by legal regulations & 33 & $10 \%$ \\
Willingness to be better than competitors & 72 & $21 \%$ \\
Sensitivity to the needs of the community & 48 & $14 \%$ \\
I don't know & 16 & $5 \%$ \\
Total & 345 & $100 \%$ \\
\hline
\end{tabular}

While proceeding to the final analysis of the part of the questionnaire, the respondents were asked to express their opinion on the following research problems:

- Can you perceive the idea of CSR in the strategy of the company?

- Do you believe in sincerity of entrepreneurs implementing the principles of CSR?

- Which of the fields of CSR activity, in your opinion, is the most important?

The analysis of the research material (see Figure 8 ) showed that $43.7 \%$ of the respondents rarely notice social responsibility in the management strategy of Polish enterprises, a bit less, i.e., $42.5 \%$ of the respondents sometimes recognize such an activity. The fact that the activities in the field of CSR in the enterprise strategy are recognized first by the managers, mainly the senior leadership (9.9\%), deserves a special attention. This must be connected with the fact that these are the ones who define the main direction of the enterprise activity and goals the enterprise should aim at.

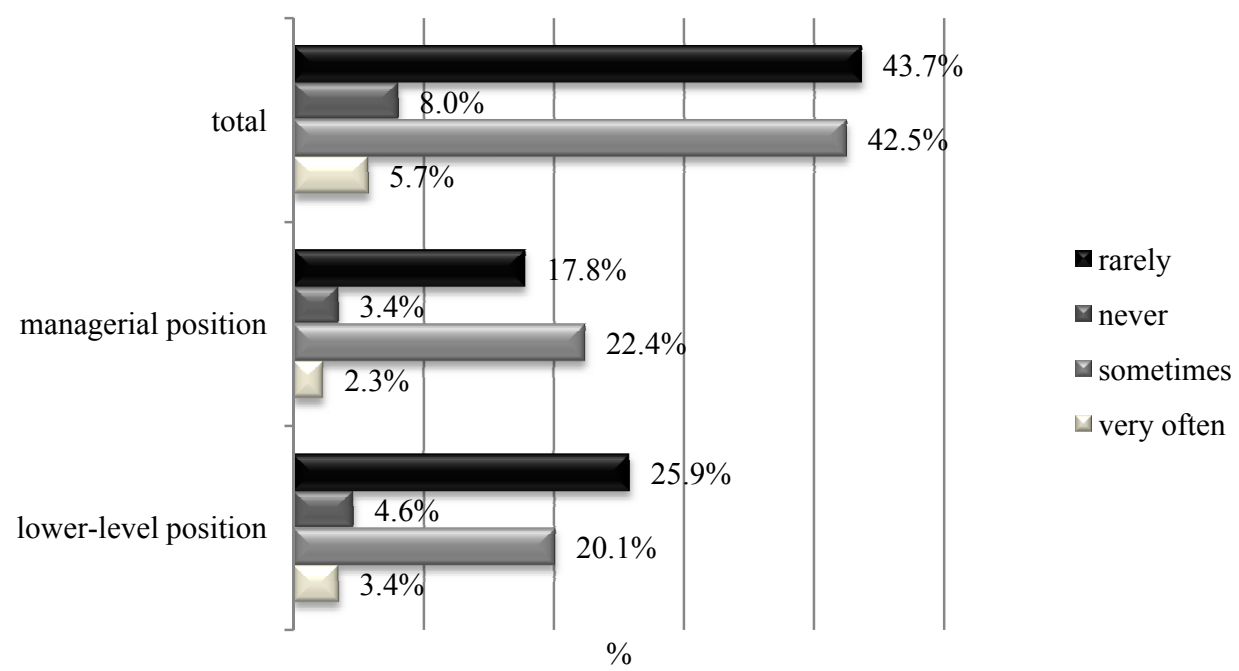

Figure 8 . The knowledge of the term of social responsibility in the opinion of Polish enterprises. 
In the light of the conducted research (see Figure 9), it occurred that socially responsible activity of enterprises raises objections. In the opinion of $56.9 \%$ of the respondents, the enterprises publicizing their CSR activity only aim at obtaining financial benefits, and consequently, increasing profits, mainly by using human emotions. Interestingly, $13.2 \%$ of regular employees and the ones holding managerial positions have different opinions.

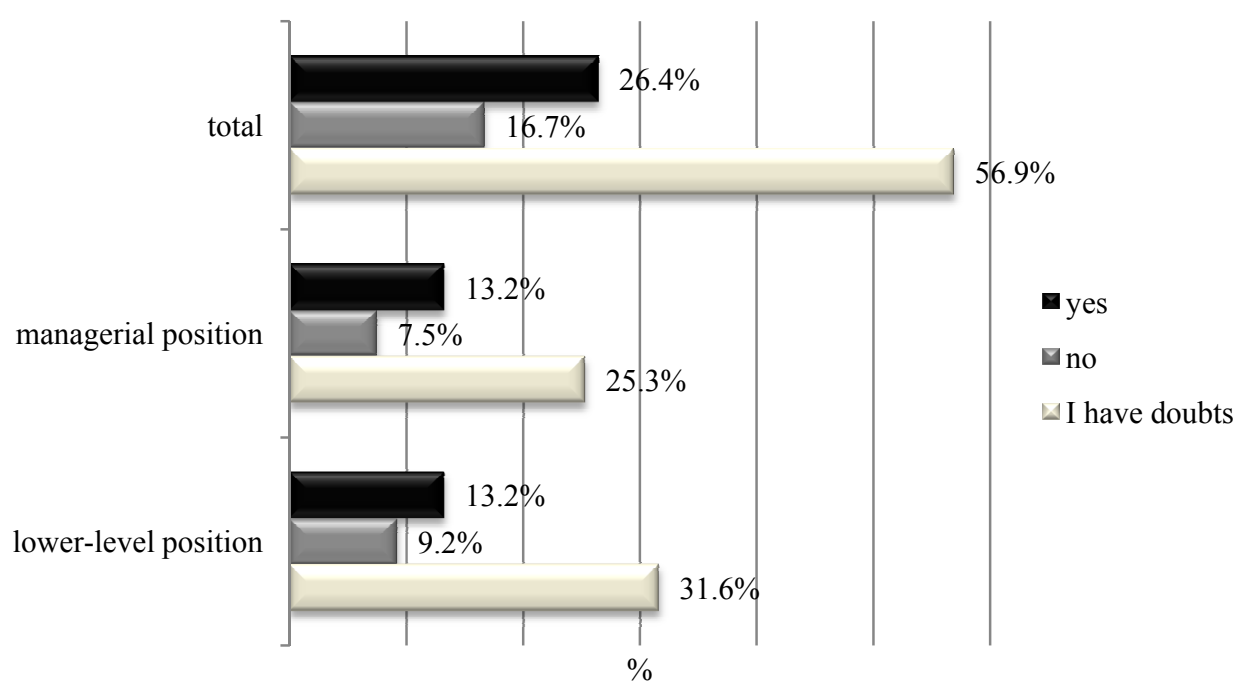

Figure 9. The knowledge of the term of social responsibility in the opinion of Polish enterprises.

Social responsibility as a voluntary concept of management of the modern enterprise, in its essence, refers to its three main aspects, i.e., the economic one (profit maximization), the social one (referring to its internal and external structure, thus, to employees and local community, and also other stakeholders), and the ecological one (the environment protection). Certainly, the CSR activity in the above aspects may be varied (see Table 5) and depends on the possibilities of a given enterprise.

Table 5

The Aspects of CSR

\begin{tabular}{|c|c|c|}
\hline The area of CSR & The key issues of CSR & Functional area \\
\hline \multirow{3}{*}{$\begin{array}{l}\text { The economic } \\
\text { aspect }\end{array}$} & \multirow{3}{*}{$\begin{array}{l}\text { fight against corruption, embezzlement and money laundering, fair } \\
\text { competition, respecting the right of property, promoting social } \\
\text { responsibility }\end{array}$} & Services \\
\hline & & Finances and investments \\
\hline & & Marketing \\
\hline \multirow{3}{*}{$\begin{array}{l}\text { The internal } \\
\text { social aspect }\end{array}$} & \multirow{3}{*}{$\begin{array}{l}\text { providing the right for equitable remuneration, fair treatment and } \\
\text { non-discrimination on grounds of gender, views, racial or ethnic origin etc., } \\
\text { providing the right for decent working conditions, health and safety at } \\
\text { work, providing the right for freedom during leisure time, inviolability, } \\
\text { participation in the decisions concerning employment }\end{array}$} & Employment and human resource \\
\hline & & Organization and management \\
\hline & & Services \\
\hline \multirow{2}{*}{$\begin{array}{l}\text { The external } \\
\text { social aspect }\end{array}$} & \multirow{2}{*}{$\begin{array}{l}\text { activities bringing about the improvement of the quality of life of the } \\
\text { society, creating partnership for the benefit of development }\end{array}$} & Finances and investments \\
\hline & & Research and development \\
\hline \multirow[b]{2}{*}{$\begin{array}{l}\text { The ecological } \\
\text { aspect }\end{array}$} & \multirow{2}{*}{$\begin{array}{l}\text { minimizing the use of resources and energy, raising awareness of the } \\
\text { influence of business activity on the natural environment, taking into } \\
\text { consideration the environmental assumptions at the stage of designing } \\
\text { innovative products and technologies }\end{array}$} & Finances and investments \\
\hline & & Research and development \\
\hline
\end{tabular}

Note. Source: Olejniczak, 2012, p. 45. 
Due to a wide range of the activities, the respondents were asked to indicate the areas in which the activity of enterprises is the evidence of its social responsibility. The analysis of the questionnaire clearly indicates that the internal social aspect referring to employees, for $70 \%$ of the respondents, constitutes the main area of the activity in the field of CSR, though, the key issues of this aspect are: relationships with employees- $22 \%$, complying with human rights-18\%. Another area of the activity is the external social aspect-15.5\%: cooperation with the local community or relationships with consumers, then, the ecological aspect.

\section{Conclusions}

The considerations (both the theoretical and practical ones) presented in the paper, referring to the concept of CSR, confirmed the thesis that social responsibility is of the key importance for Polish enterprises. Moreover, Polish enterprises feel the increased need to implement the activities in the field of social responsibility, which, in the present conditions, constitutes an important part of running a business activity. It is true that there is still a long way to balance the economic goals with ethical actions, including the activities referring to social responsibility but, in the opinion of the respondents, CSR may become one of the conditions of achieving competitive advantage on the market, and also it may bring about the increase in effectiveness and efficiency of work, which, in turn, will affect the increase in profits, and simultaneously the success of the enterprise.

\section{References}

Adamczyk, J. (2009). Corporate social responsibility: Theory and practice (Spoleczna odpowiedzialność przedsiębiorstw: Teoria i praktyka). Warszawa: PWE.

Carroll, A. B., \& Buchholtz, A. K. (1999). Business \& society-Ethics and stakeholder management. Ohio: South-Western College Publishing.

CSR in Poland: Baseline study. (2007). Warszawa: Program Narodów Zjednoczonych ds. Rozwoju.

Ćwik, N. (2011). The development of CSR in Poland. Warszawa: RespEN, Forum Odpowiedzialnego Biznesu.

Drucker, P. F. (1994). The practice of management (Praktyka zarzqdzania). Kraków: AK w Krakowie.

Friedman, M. (1970). The social responsibility of business is to increase ITS profits. New York Magazine.

Griffin, R. W., \& Ebert, R. J. (2006). Business. Upper Saddle River, NJ: Prentice Hall.

Ingley, C. B. (2008). Company growth and board attitudes to corporate social responsibility. International Journal of Business Governance and Ethics, 4, 17-39.

Kroik, J., \& Bachorski-Rudnicki, M. (2010). The genesis and development of the concept of corporate social responsibility (Geneza i rozwój koncepcji społecznej odpowiedzialności biznesu). Problemy Jakości No. 10.

Murrey, A. (2003). Corporate social responsibility in the UE. London: Centre for European Reform.

Olejniczak, K. (2012). Społeczna odpowiedzialność a kreowanie przewagi konkurencyjnej. Częstochowa: SWWZPCz.

Olejniczak, K. (2013). The projects of socially responsible as a multidimensional area of modern enterprise management (Przedsięwzięcia społecznie odpowiedzialne jako wielowymiarowy obszar zarzadzania współczesnym przedsiębiorstwem, w: Wyzwania globalne i lokalne zarzadzania podmiotami gospodarczymi) (pp. 40-47). Częstochowa: SWW. 